\title{
Petrophysical Investigation of the Secondary Recovery Potential in the Cherry Canyon Formation NE Lea Field Lea County, New Mexico
}

Final Technical Report

Reporting Period

$1 / 10 / 00$ to $6 / 30 / 01$

Report Date

June, 2002

Grant No. DE-FG26-00BC15256

Read and Stevens, Inc.

P.O. Box 1518

Roswell, New Mexico 88202

Prepared by:

T. Scott Hickman \& Associates, Inc.

505 North Big Spring, Ste. 105

Midland, Texas 79701 


\section{Disclaimer}

This report was prepared as an account of work sponsored by an agency of the United State Government. Neither the United States Government nor any agency thereof, nor any of their employees, makes any warranty, express or implied, or assumes any legal liability or responsibility for the accuracy, completeness, or usefulness of any information, apparatus, product, or process disclosed, or represents that its use would not infringe privately owned rights. Reference herein to any specific commercial product, process, or service by trade name, trade mark, manufacturer, or otherwise does not necessarily constitute or imply its endorsement, recommendation, or favoring by the United States Government or any agency thereof. The views and opinions of authors expressed herein do not necessarily state or reflect those of the United States Government or any agency thereof. 


\section{Index}

Abstract

Page

Introduction and Discussion

Conclusions

Reservoir Model and Patterns

Economic Criteria

\section{List of Figures}

Figures

1
2
3
4
5
6
7
8
9
10
11
12
13

Location of Model Area

Page

"As-Is" Five Spot Waterflood Pattern

40 Acre 5-Spot Production Prediction

"Ideal" Five-Spot Pattern

"Ideal" Five-Spot Production Prediction

Full Line Drive Waterflood Pattern

Full Line Drive Production Prediction

East-West Line Drive Pattern

East-West Line Production Prediction

Infill Drilling Waterflood Pattern 18

Infill Drilling with Waterflood Prediction $\quad 19$

Infill Drilling without Waterflood Pattern $\quad 20$

13

Infill Drilling without Waterflood Prediction

\section{List of Tables}

Table 1

Table 2

Table 3

Table 4

Table 5

Table 6

Table 7

Table 8
Comparison of Reserves and Economics 22

"As-Is" Five Spot Reserves and Economics 23 Ideal Five Spot Reserves and Economics 24

Full Line Drive Reserves and Economics 25

East-West Line Drive Reserves and Economics 26

Probable Infill w/ Waterflood " " " " 27

Probable Infill without Waterflood " " $\quad 28$

Economic Data Used for Cash Flows 29 


\section{$\underline{\text { ABSTRACT }}$}

Read \& Stevens has proposed the evaluation of the waterflood potential from the Cherry Canyon formation in the NE Lea Field in Lea County, New Mexico. Much of the development in this area is approaching primary recovery limitations; additional recovery of remaining oil reserves by waterflood needs to be evaluated.

The Cherry Canyon formation is composed of fine grained sandstone, containing clay material which results in high water saturation, and also has the tendency to swell and reduce reservoir permeability - the ability of fluid to flow through the rock pores and fractures. There are also abundant organic materials that interfere with obtaining reliable well logs. These complications have limited oil in place calculations and identification of net pay zones, presenting a challenge to the planned waterflood.

Core analysis of the Cherry Canyon should improve the understanding of existing well logs and possibly indicate secondary recovery measures, such as waterflood, to enhance field recovery. Lacking truly representative core to provide accurate analyses, Read and Stevens will obtain and preserve fresh core. The consulting firm of T. Scott Hickman and Associates will then collaborate on special core analyses and obtain additional well logs for a more detailed analysis of reservoir properties. The log interpretation will be compared to the core analysis results, and the entire collected data set will be used to assess the potential and economic viability of successfully waterflooding the identified oil zones. Successful results from the project will improve accuracy of $\log$ interpretation and establish a methodology for evaluating secondary recovery by waterflood. 


\section{TECHNICAL PROGRESS REPORT}

\section{INTRODUCTION}

The Northeast Lea Cherry Canyon represents a significant oil accumulation. On the Read \& Stevens-operated leases a total of $2.9 \mathrm{MMBO}$ has been produced through June 2001, the majority of which has been from the Cherry Canyon. Many individual wells will have ultimate primary reserves in excess of $100 \mathrm{MBO}$ and 40-acre volumetric calculations indicate primary recoveries in excess of $15 \%$ of the OOIP. Such performance indicates good permeability and reservoir continuity, suggesting that the reservoir is a waterflood prospect. On the other hand the Cherry Canyon is an extremely fine grained sand with a significant clay content that has a high water saturation. Cherry Canyon wells usually produce at a high water cut and it is difficult to determine from log and core analysis whether a zone is water or oil productive. Even if the oil productive zone can be identified, it is usually necessary to fracture treat the well upon completion to get beyond wellbore damage; hence the oil zones can not be isolated.

Industry has had very little experience with water flooding the Cherry Canyon. A literature search prior to undertaking this study revealed a few projects in New Mexico that were reported to be Cherry Canyon waterfloods. Only one, Indian Draw, had any extensive performance history. Although response to injection has occurred, the reservoir was several thousand feet shallower than that at Northeast Lea and probably is not a good analogy. In all cases there was confusion as to exactly what formation was being injected into. Most projects were injecting into both the Cherry Canyon and Brushy Canyon and in some cases the Upper Delaware, i.e. Bell and/or Ramsey Sands, was opened. The Bell and Ramsey Sands are proven waterflood prospects and are not analogous to the Cherry Canyon.

Read \& Stevens commissioned T. Scott Hickman \& Associates to conduct a waterflood study on the Northeast Lea Cherry Canyon reservoir. A detailed geological description was obtained on unpreserved cores from two wells which indicated a large amount of fine layered shale/sand lamination which would affect log response and calculate erroneously high water saturation (Sw) values. The prediction of waterflood performance in an untried formation would require accurate $S w$ values and valid relative permeability data for each rock type that might be present. It was decided that a preserved core would be cut for petrophysical analysis on the next well Read \& Stevens drilled. Since the project was expanding in scope and complexity beyond what was originally envisioned, application was successfully made for a $\$ 75,000$ grant from the DOE under a special program for small independent operators. 
The core was cut in early 2000 and the rest of the year was spent on conducting and interpreting special core analysis to define the reservoir's petrophysical relationship by rock types. A detailed core description with thin section petrography and depositional environment and sequence interpretation was performed by Fred Behnken. This report showed that shale lamination was not a problem and the study procedure was adjusted accordingly.

Both conventional and special logs suites had been run on the test well. The log interpretation results were combined with the petrophysical relationships from core to create a reservoir model for simulation. History matching with the simulator started in the spring of 2001. By early summer the model was calibrated and ready for waterflood predictive runs. Belatedly it was discovered that the commercial simulator being utilized did not have an oil hysteresis option which is needed to predict waterflood performance in a strongly water wet rock. Without this feature the results would be too optimistic. The software company acknowledged their omission, but development and inclusion of the hysteresis feature would take about a month. It was decided to go ahead with the waterflood predictive runs. If the results were not economic then there would be no need to run the hysteresis option.

However, the results were marginally economic so the hysteresis feature was used once it became available. Unfortunately, in the process of installing the new feature the programmer also made some change in the PVT processor and a couple of weeks were lost in reestablishing the original PVT relationships in the model. The simulator results were run through the OGRE economic model and the resulting cash flow clearly showed that waterflooding was not a viable option.

\section{CONCLUSIONS}

1. Within the study area the Northeast Lea Cherry Canyon reservoir has demonstrated good primary performance with individual wells estimated to have primary recovery on the order of $15 \%$ of their OOIP on a 40 acre basis.

2. The Cherry Canyon producing formation is a fine grained sand that is strongly water wet due to a coating of non-swelling clay around the individual sand grains. Due to the fine grain size and presence of certain types of clay, the average pore throat size is about 1.5 microns.

3. Even though both core analysis and performance indicate good oil permeability, the combination of water wetness and small pore throats creates unfavorable water relative permeability conditions for the recovery of secondary oil by waterflood. 
4. The unfavorable conditions are manifested in low water injection rates, lack of sufficient banking of oil and extremely long reservoir pressure build up and oil response time.

5. Pressure maintenance by water injection initiated early in the reservoir producing life might have been economically successful. The simulation predictions indicate that reservoir voidage is now too large for pressure maintenance to be effective.

6. The simulation results predicted that infill drilling without water injection would not be economically successful.

7. Experience in history matching the primary performance during simulation suggests that there may be some unrecognized compartmentalization in the model area. Such a situation would not improve the waterflood potential, but might impact primary infill drilling in terms of undrained areas.

8. The irregular spacing of wells in the Northeast Lea Cherry Canyon reservoir prevents development of uniform injection patterns. This situation decreases the sweep and increases the costs. However, the results from the simulation of idealized uniform patterns still show that waterflooding is not economically viable.

9. The injection pressure in the simulator was held below formation parting pressure. Historically many operators in the Permian Basin have injected above parting pressure to increase injection rates. It is doubtful that such a practice at Northeast Lea would improve waterflood performance.

10. Secondary recovery by miscible $\mathrm{CO} 2$ flooding has not been investigated. Such a technology might have much better relative permeability than water which would allow higher injection rates and faster processing of the pore volume. However, since the reservoir could not be effectively repressured initially with water or the miscible bank driven by water, the volume of $\mathrm{CO} 2$ required would be much greater in relative terms than for a conventional tertiary $\mathrm{CO} 2$ project. 


\section{RESERVOIR MODEL}

A reservoir model was constructed for the southwest quarter-section area of Section 3, Township 20S, Range 34E for use in a three dimensional, black oil numeric simulator (Figure 1). The active wells in the model area are the Mark Federal Nos. 1, 2,5 and 6 . These wells were selected for the model based on the quality of the Cherry Canyon in the area in addition to the understanding that these wells have never produced from a reservoir other than the Cherry Canyon. Three Cherry Canyon sand members, "A", "B" and " $\mathrm{C}$ ", were set up as individual layers in the model. Due to its low structural position and limited productivity, it was assumed that no water would be injected into the " $\mathrm{C}$ " sand. The rock and fluid properties assigned to each layer were based on the extensive petrophysical study conducted on preserved cores from the North Lea Federal No. 11 well. Although this test well was on the edge of the structure and exhibited limited productivity, the petrophysical relationships developed from it appeared to be applicable to the main reservoir based on a comparison of conventional core porosity and permeability values.

The reservoir model was calibrated by matching the reported primary performance. The history matching process is dependent on the allocation of production to individual wells. It has been our experience that the allocations in New Mexico, where per well allocations are required monthly, are reasonable when reported by a responsible operator. A usable match was obtained on three of the four wells. The lack of a match on the fourth well appears to be due to compartmentalization or zonation, but the impact is not sufficient to change the conclusion about waterflooding.

\section{PATTERNS}

Numerous waterflood scenarios for four different pattern configurations - fivespot, line drive, conversions and 20-acre infill drilling - were investigated with the simulator. Two additional cases were also simulated: 1) an "ideal" five-spot in which the producers were centered within each injection pattern and 2) an infill drilling case without water injection. Although the reservoir is developed more or less on 40 ac /well density, the actual spacing is highly irregular. This not only creates a problem with areal sweep due to non-uniform injection patterns, but necessitates the drilling of extra wells to give continuous development. With uniform spacing, five-spot or line drive patterns can be created either by well conversion or infill drilling with all but the interior producer being shared in common with other patterns, greatly reducing the investment per pattern. This is not the case in parts of the Northeast Lea Cherry Canyon reservoir including the model area. It was necessary to look at a large number of pattern options, most of which required drilling numerous wells. However, well cost sharing was assumed on most scenarios since there would be some cost sharing if the reservoir was developed for waterflooding. 
A five-spot pattern scenario was evaluated that used the current wells as interior producers and drilled nine injectors (Figure 2). This is referred to as the "AsIs" five-spot pattern. Some cost sharing with offset patterns was assumed so drilling costs were based on four net wells. The predicted performance from the simulator is shown on Figure 3. Although the repressuring effects of injection start moderating the primary decline within the first year, the secondary increase over primary performance is not significant until ten years after injection starts. The cash flow projection (Table 2) gives negative economics. To study the impact of irregular spacing an "ideal" scenario was created in which the four existing producers were centered within uniform five-spot injection patterns (Figure 4). The drilling of nine (four net) injectors was required. Theoretically this would result in a more balanced sweep and higher recovery. As seen on the performance projection (Figure 5) the recovery was increased, but the response time was delayed by an extra two years so the economics remained negative (Table 3 ). The response delay is due to all of the injectors being further from producers than is the case with irregular spacing.

A line drive pattern scenario was investigated that required the drilling of nine (six net) injectors (Figure 6). The line drive secondary response is similar to the fivespot in that response is slow and amounts to little more than arresting the primary decline (Figure 7). As a result the economics are negative (Table 4).

Three well conversion scenarios - diagonal, north/south and east/west - were developed to investigate the effect of minimizing-capital expenditure. Each pattern yielded two producers and two injectors for the quarter-section pattern (Figure 8). The performance projection for all three conversion scenarios resulted in the loss of production for six plus years from converting two wells to injection. The best response of the three scenarios was the east/west conversion (Figure 9), but its economics on a present worth basis were negative (Table 5).

An infill drilling scenario was modeled that required the drilling of four producers and seven injectors (Figure 10). The simulator generated performance projection (Figure 11) shows an initial increase in oil rate due to primary production from infill producers. The impact of reservoir repressuring due to water injection is felt within two years in the form of lessening the primary decline. A production response is experienced within five years, which is sooner than for the other patterns tested due to reduced spacing. However, this scenario is very capital intensive and the economics are negative (Table 6).

To look at the economics of infill drilling under primary conditions, the injectors were omitted and the scenario rerun through the simulator (Figure 12). The performance projection (Figure 13) shows how rapidly the initial infill producers' rates decline without any type of pressure support. The dropping of the "existing + infill" rate below the existing rate after seven years indicates that the infill wells are being 
drilled within the drainage areas of existing wells. The economics for the scenario were negative (Table 7) and none of the four infill locations were individually economical.

\section{ECONOMIC CRITERIA}

Table 8 outlines the capital costs assumed for the cash flow analysis. The price and escalation scheme and primary discount rate are in accord with current industry practices. The use of assumed rather than existing economic parameters affects the cash flow projections by the difference in prices and expenses and can have a major effect on the economic viability of undeveloped reserves. We express no opinion as to future oil and gas prices, but rather depend on the NYMEX oil and gas future strip prices to establish prices over the next several years and the trend of prices into the future as discussed below.

Future product prices were based on the NYMEX (WTI spot) oil and NYMEX $(\mathrm{HH})$ gas five-year strip futures as of July 27,2001 after adjusting for gravity and transportation. The oil price was not adjusted for the differential between spot and posted prices. Using a more current five-year strip futures basis and making the price differential adjustment would result in a slightly lower oil price than input for this cash flow analysis. The prices were not revised since it would result in even less favorable economics. Lease operating expenses were adjusted from historical data provided by the operator. Investments were also adjusted from historical data provided by the operator. Investment costs for injection wells near the pattern edges were allocated, assuming adjacent patterns would be completed. Expenses and investments were held constant for the life of the properties. Costs of $20 \mathrm{\xi} / \mathrm{bbl}$ for acquiring makeup injection water are based on experience. No salvage value or abandonment costs were included for the properties. 


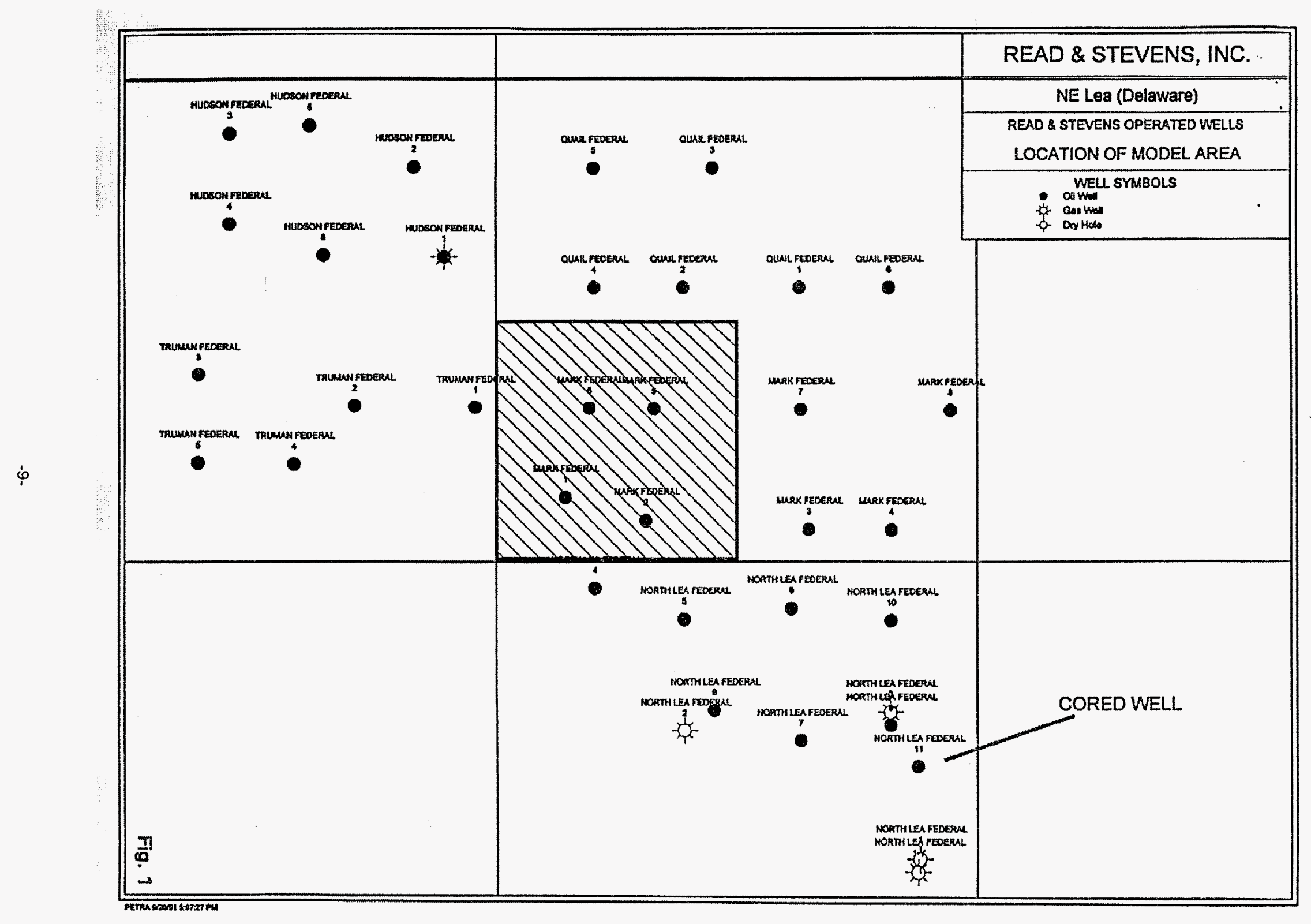




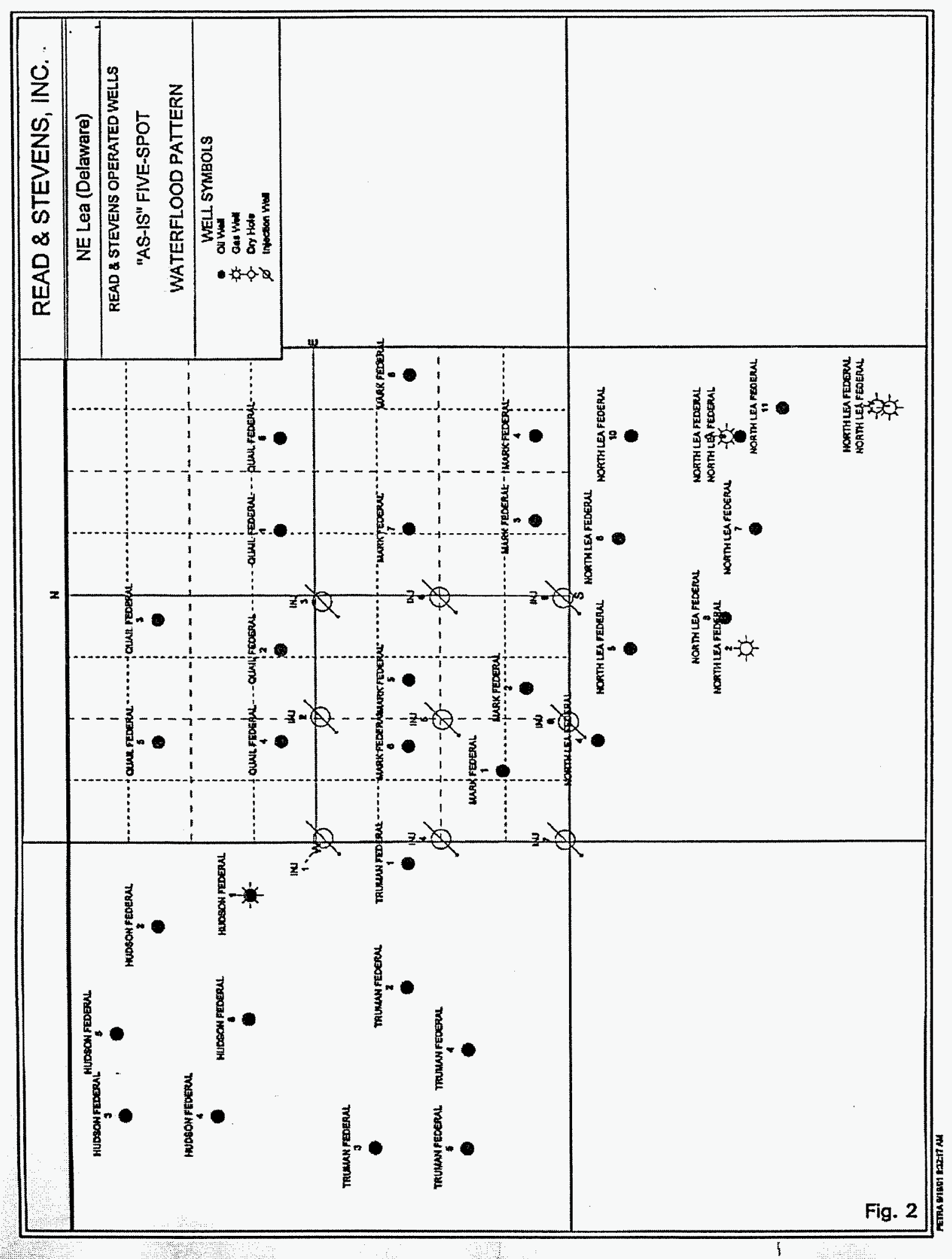




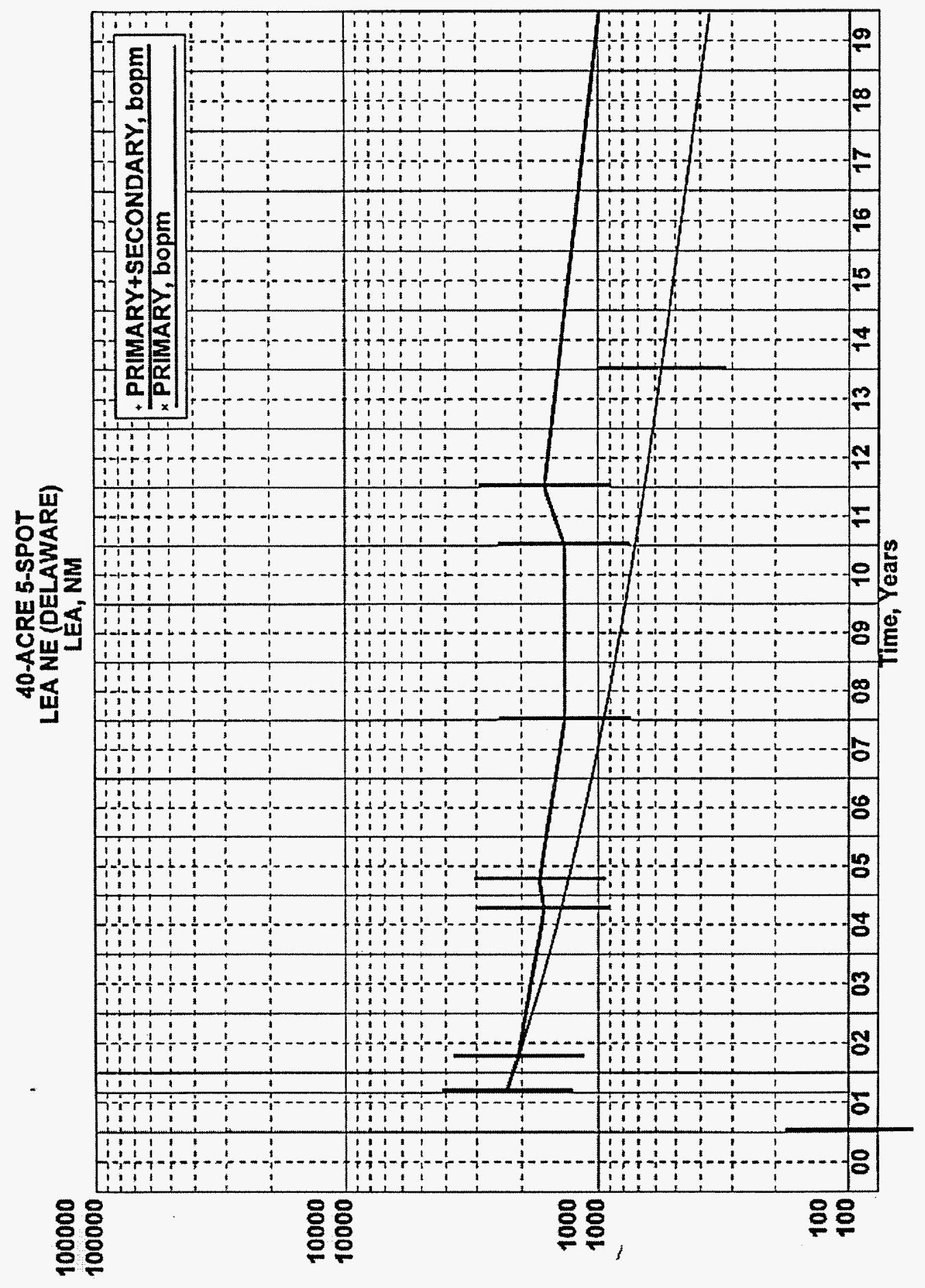

Fig. 3 


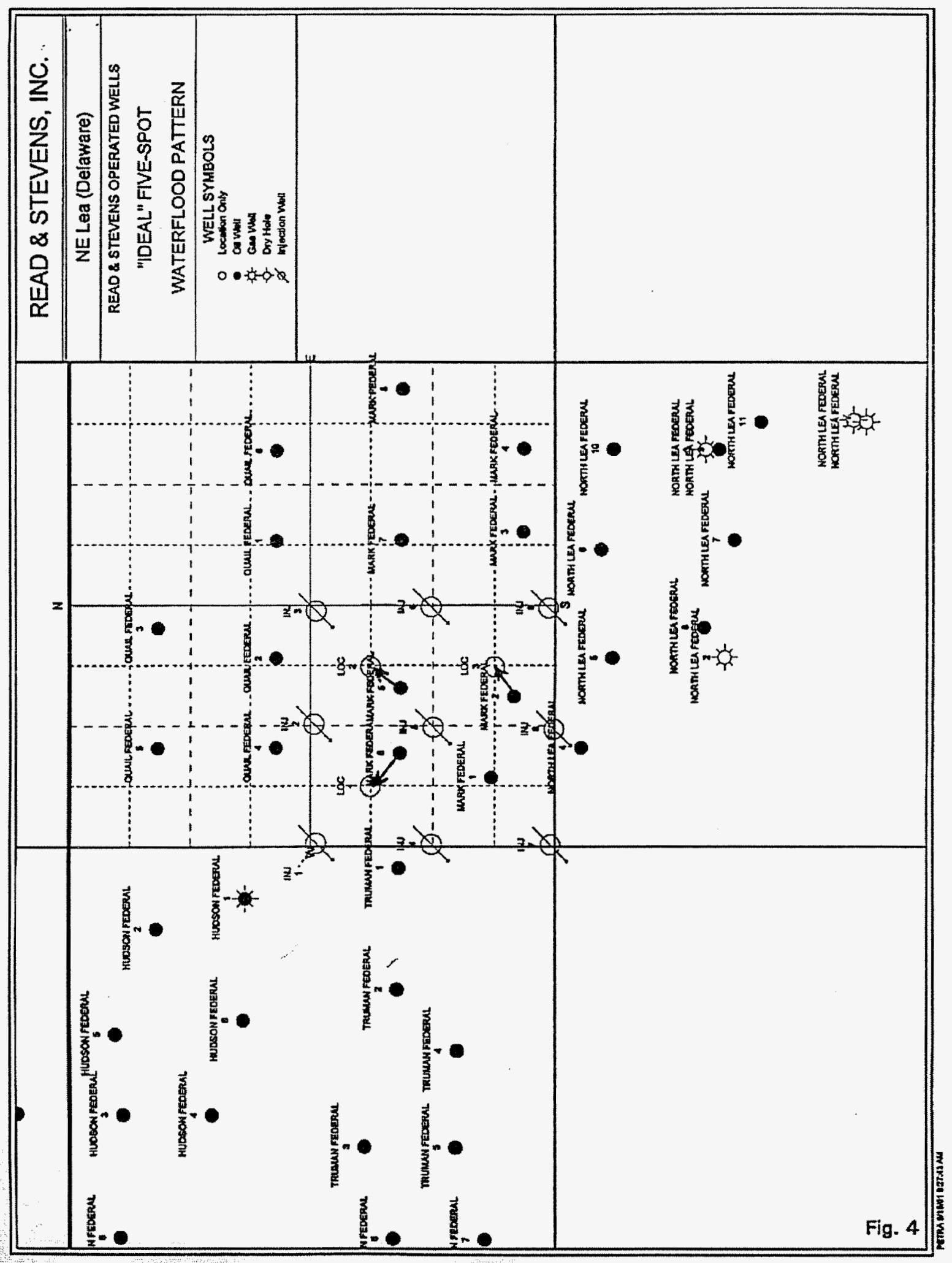




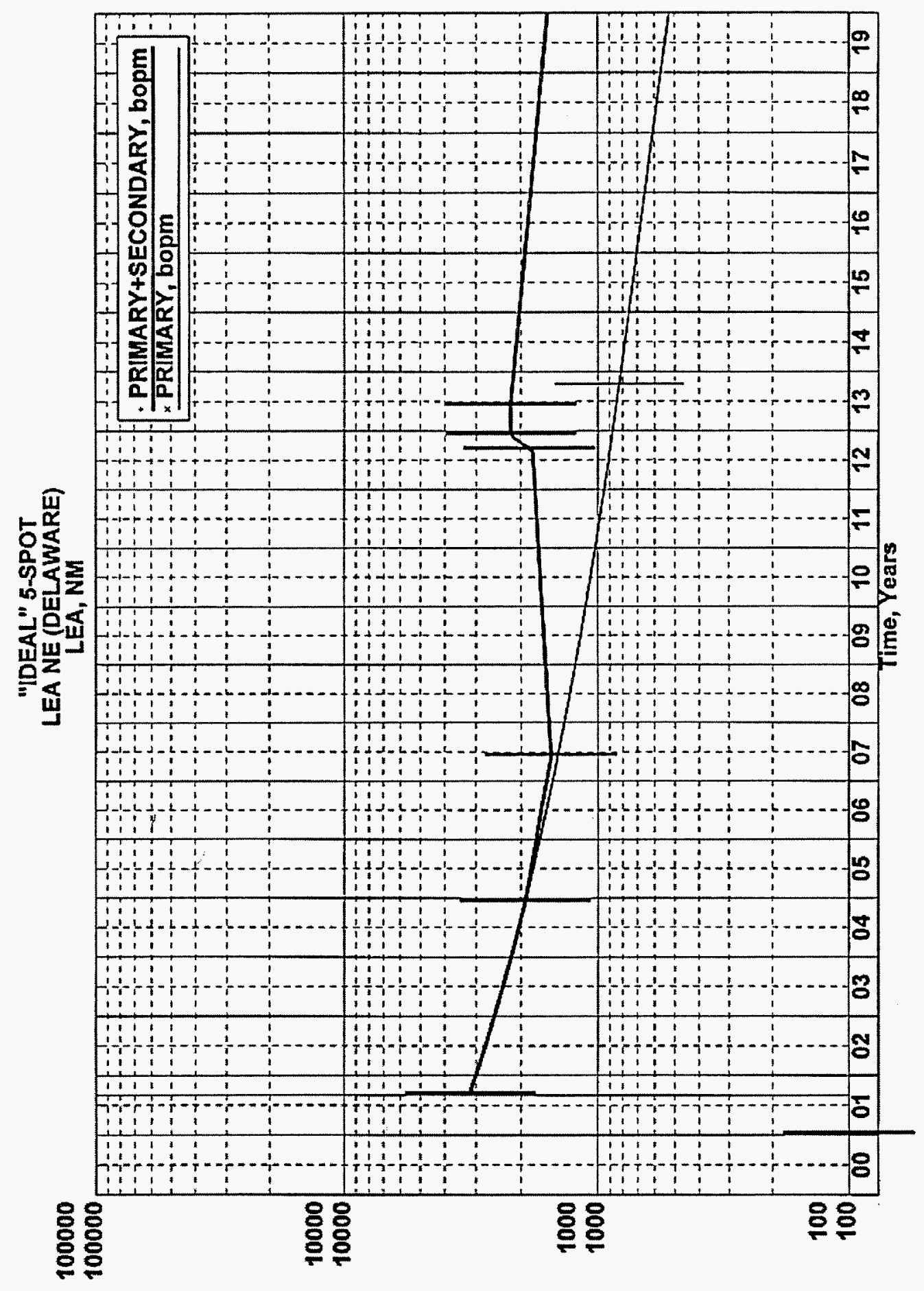

Fig. 5 


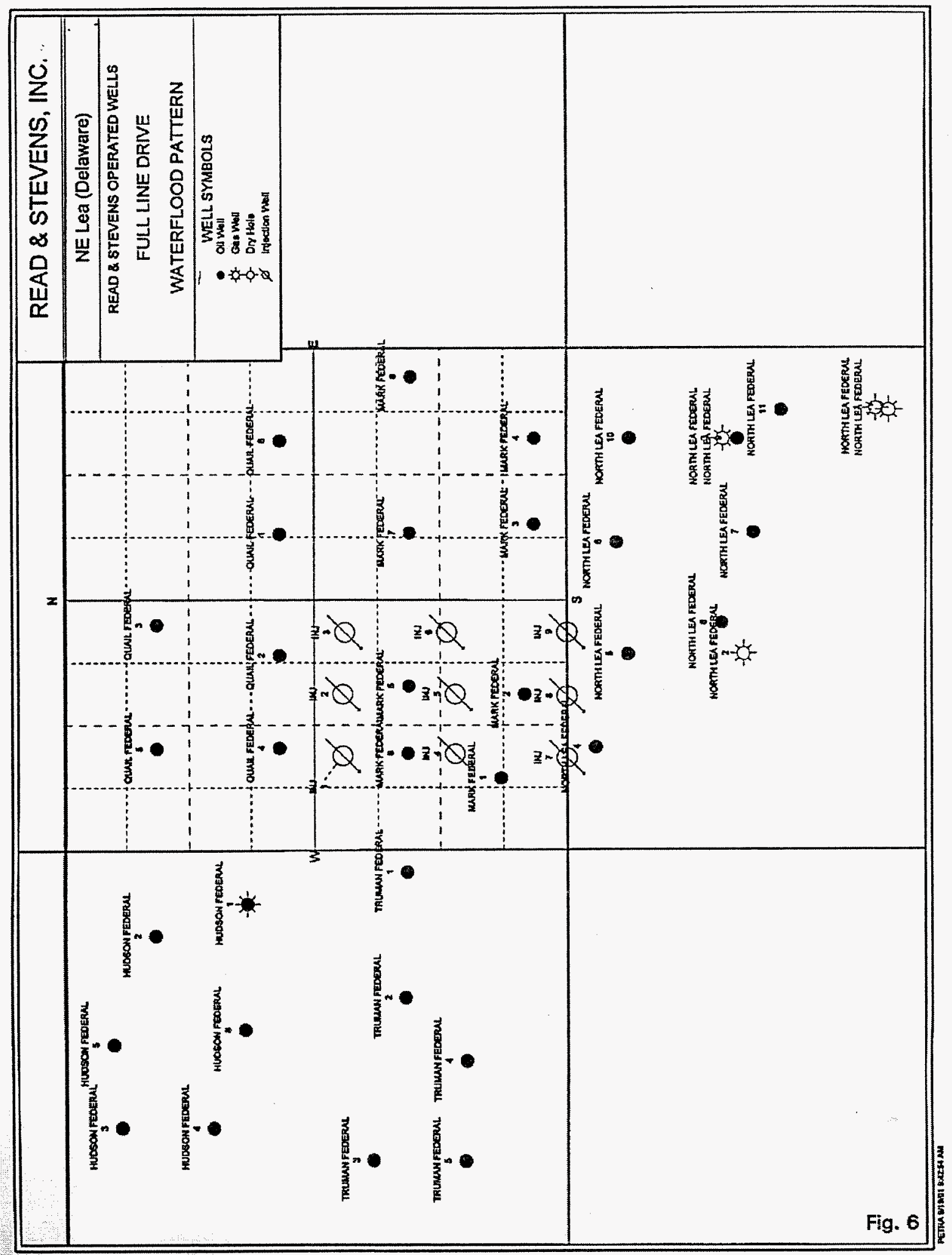




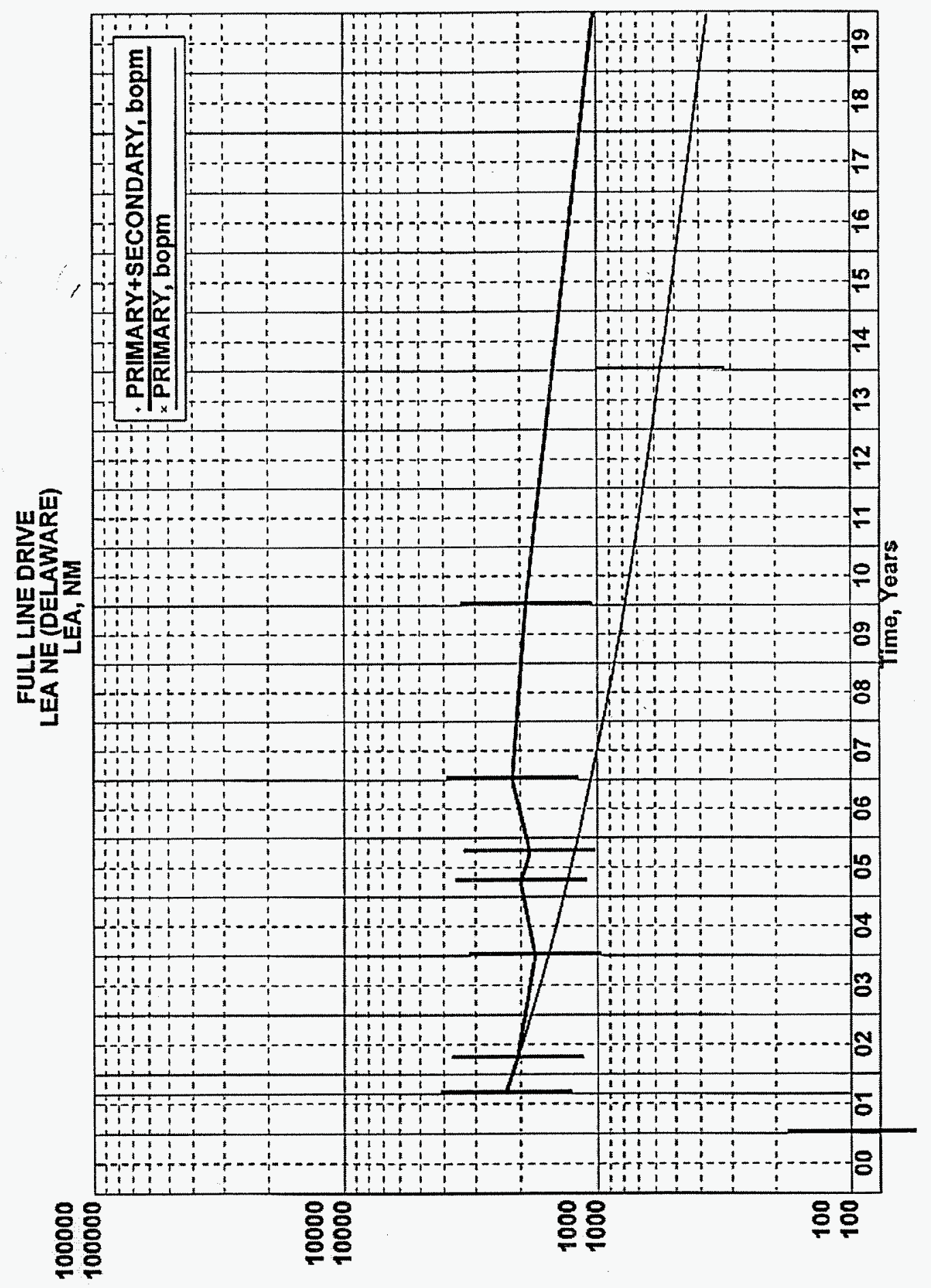

Fig. 7 


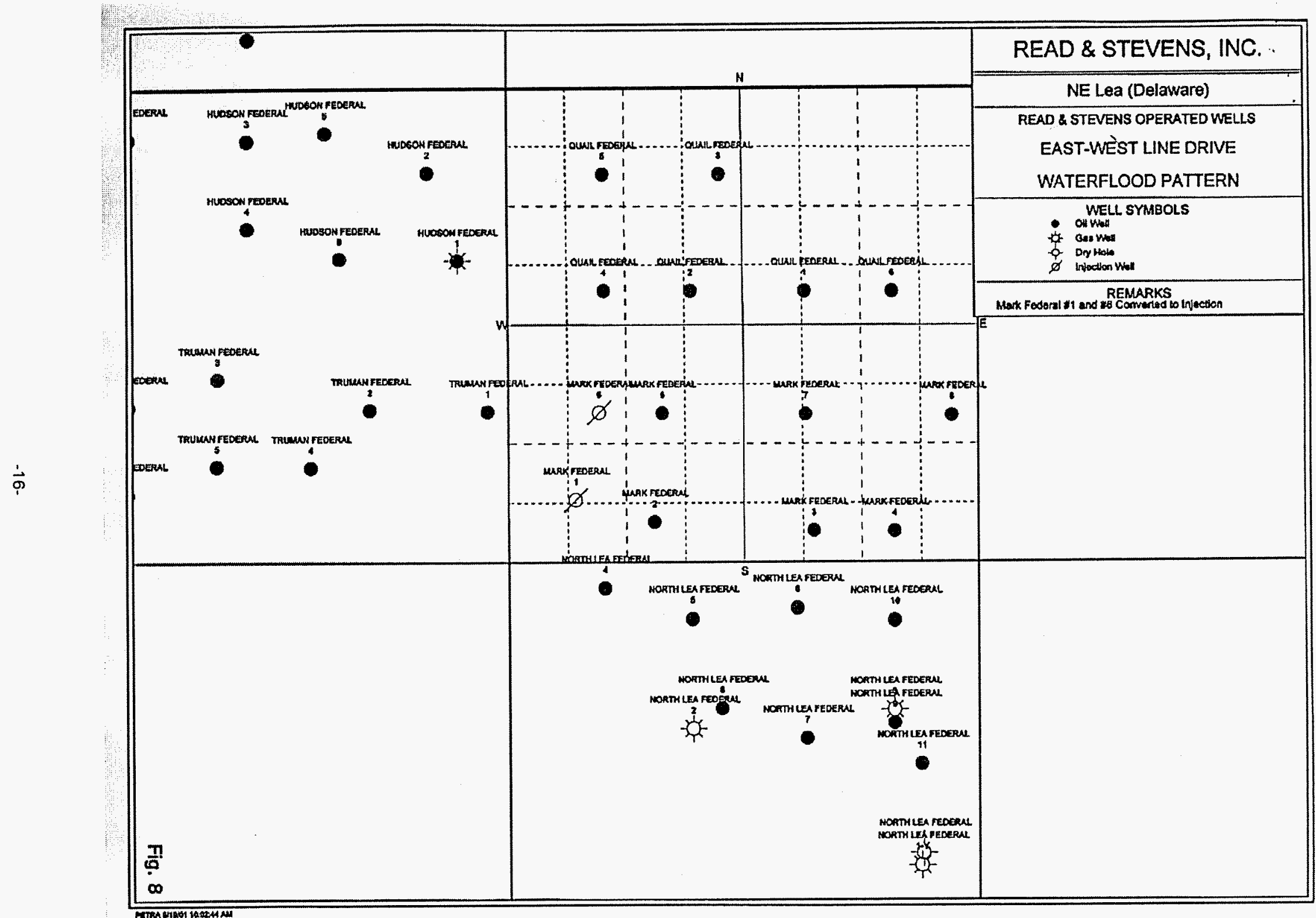




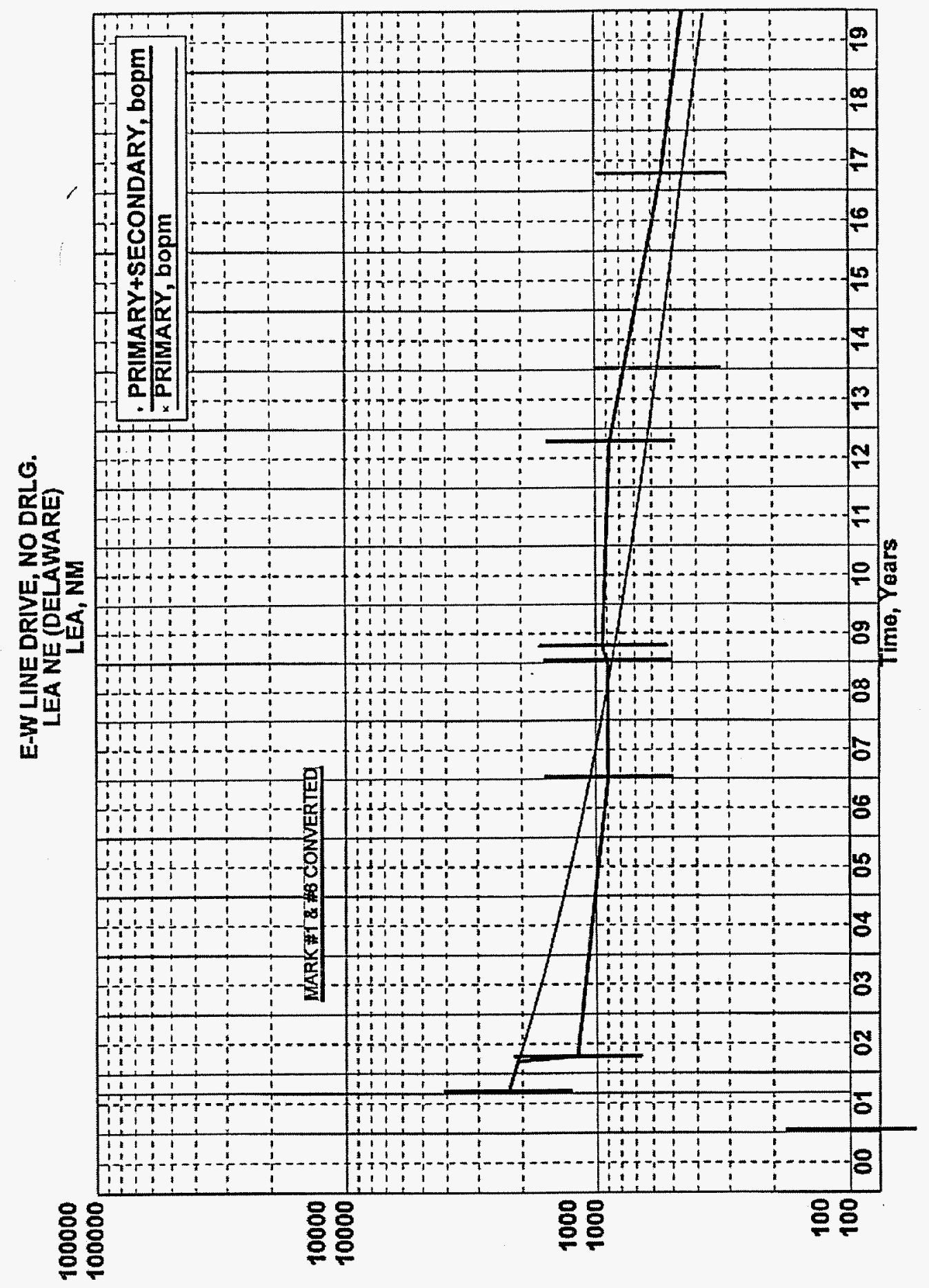

Fig. 9 


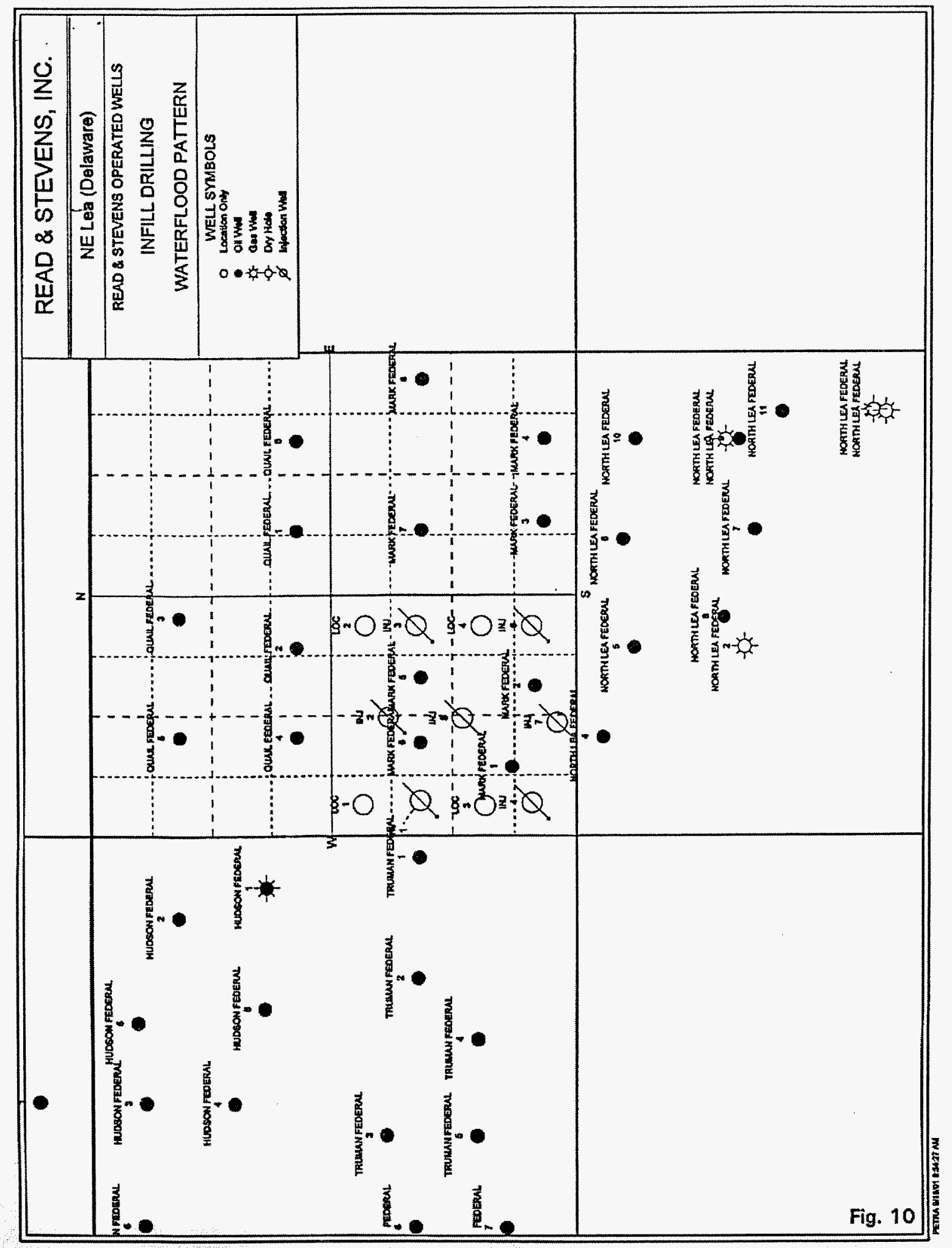




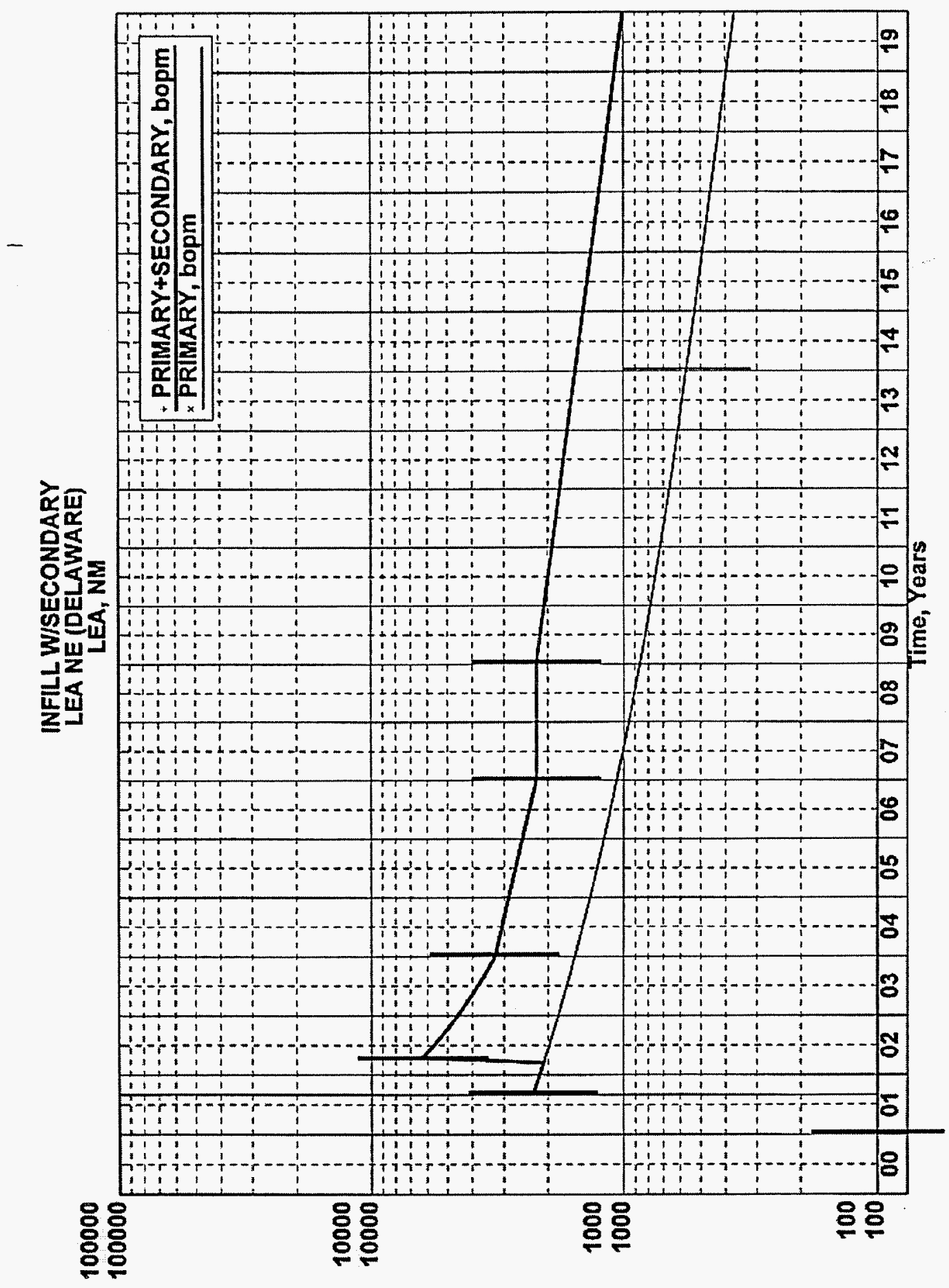

Fig. 11 


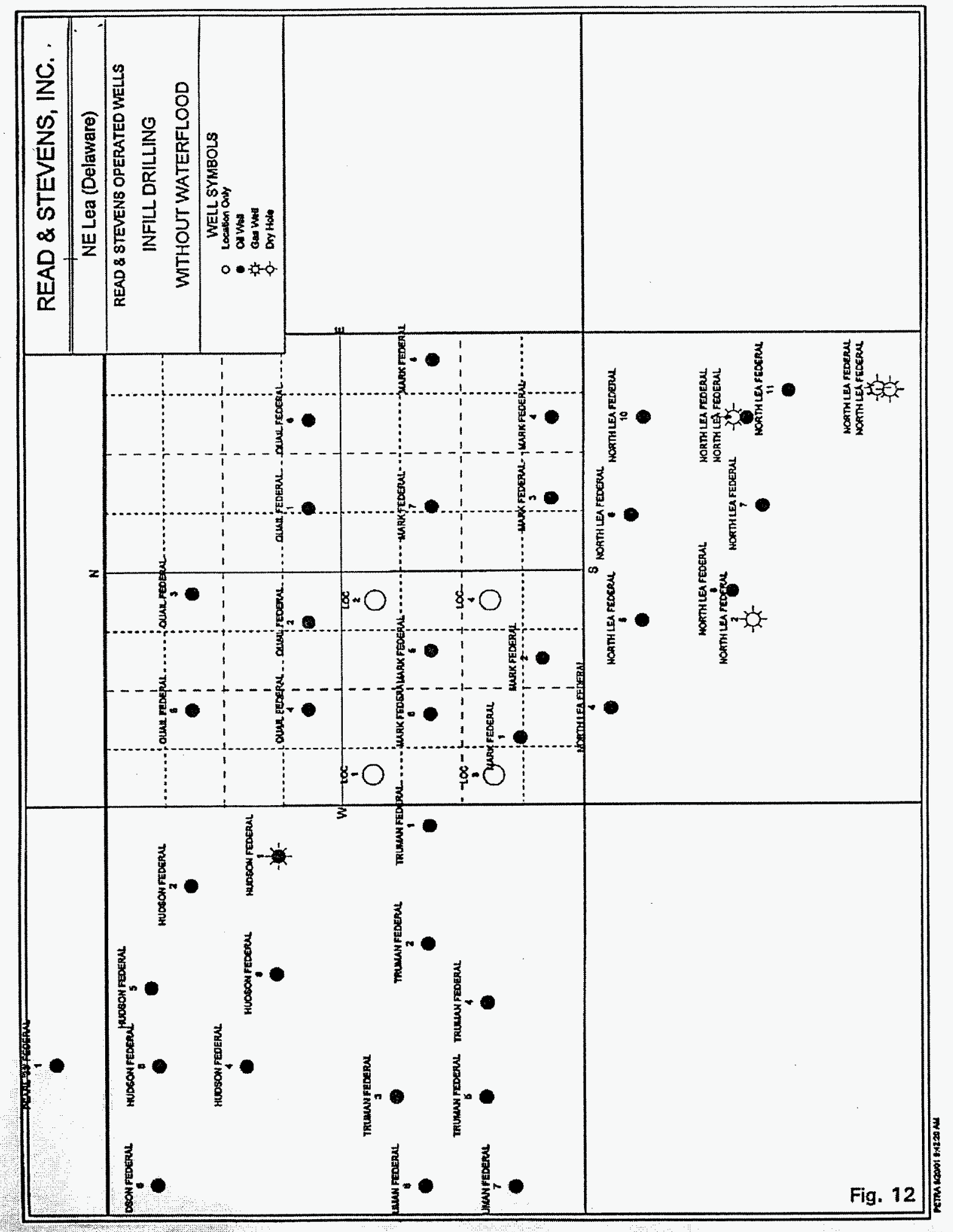




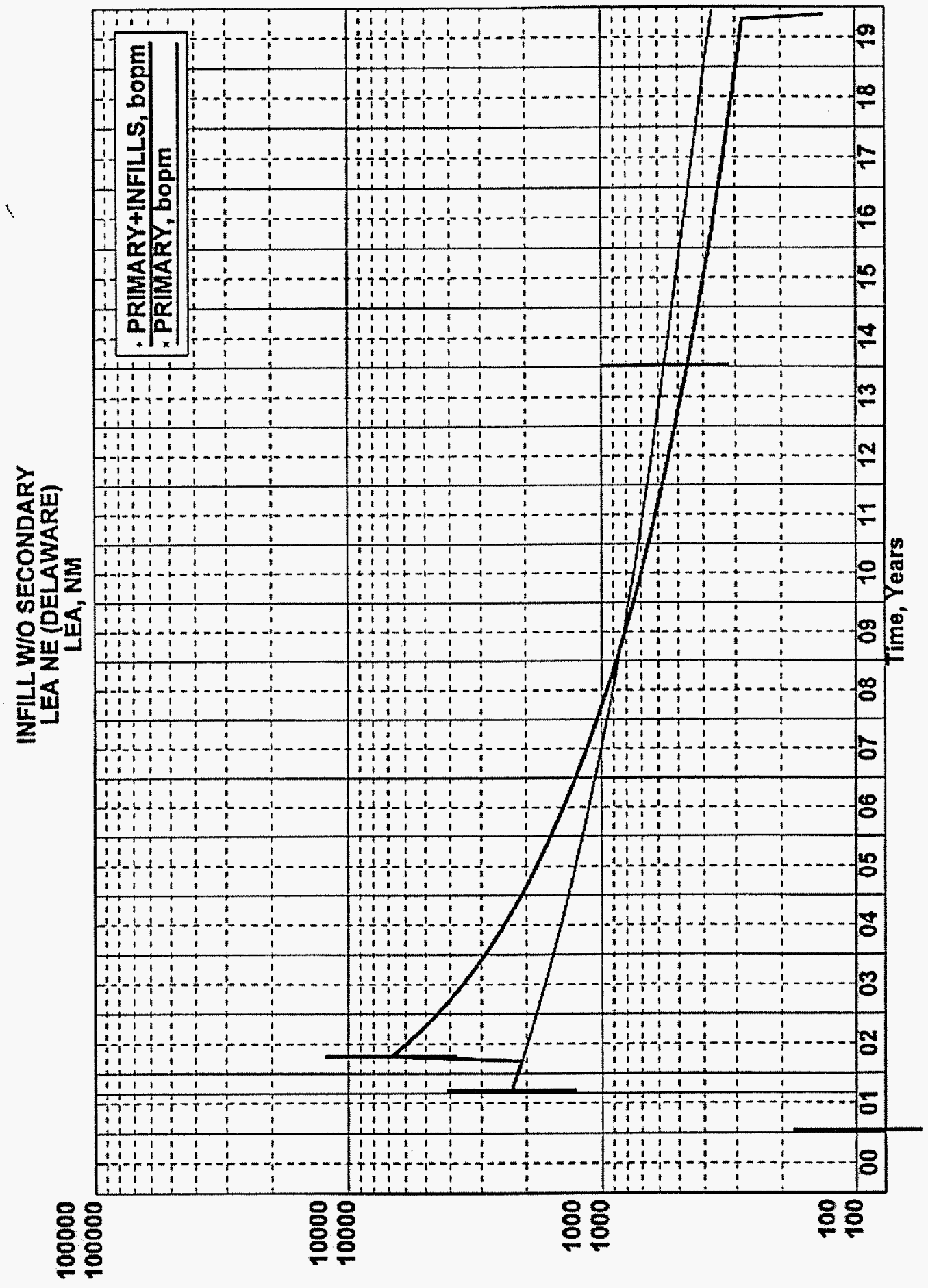

Fig. 13 
TABLE 1.

COMPARISON OF RESERVES \& ECONOMICS

PROPOSED WATERFLOOD PROJECT

NORTHEAST LEA (DELAWARE) FIELD

LEA COUNTY, NEW MEXICO

\begin{tabular}{|l|c|c|c|c|c|}
\hline SCENARIO & $\begin{array}{c}\text { RESERVES, } \\
\text { MBO }\end{array}$ & $\begin{array}{c}\text { RECOVERY } \\
\text { FACTOR, } \\
\% \text { OOIP (1) }\end{array}$ & $\begin{array}{c}\text { S:P } \\
\text { RATIO }\end{array}$ & $\begin{array}{c}\text { 8/8THS } \\
\text { DEVELOPMENT } \\
\text { COST, \$M }\end{array}$ & $\begin{array}{c}\text { UNDISCOUNTED } \\
\text { FUTURE NET } \\
\text { REVENUE, \$M }\end{array}$ \\
\hline PRIMARY & 689.5 & 14.7 & - & - & 2,281 \\
\hline $\begin{array}{l}\text { "AS-IS" } \\
\text { FIVE-SPOT }\end{array}$ & 127.2 & 2.7 & 0.18 & 1,890 & $(1,712)$ \\
\hline $\begin{array}{l}\text { "IDEAL" FIVE- } \\
\text { SPOT }\end{array}$ & 233.3 & 5.0 & 0.34 & 1,890 & $(2,019)$ \\
\hline $\begin{array}{l}\text { FULL LINE } \\
\text { DRIVE }\end{array}$ & 149.1 & 3.2 & 0.22 & 2,835 & $(2,943)$ \\
\hline $\begin{array}{l}\text { ENW LINE } \\
\text { DRIVE }\end{array}$ & 20.9 & 0.4 & 0.03 & 100 & 55 \\
\hline $\begin{array}{l}\text { INFILL WI } \\
\text { WATERFLOOD }\end{array}$ & 140.7 & 3.0 & $0.20^{(2)}$ & 5,878 & $(5,213)$ \\
\hline $\begin{array}{l}\text { INFILL WIO } \\
\text { WATERFLOOD }\end{array}$ & 28.2 & 0.6 & - & 2,520 & $(1,569)$ \\
\hline
\end{tabular}

(2) Percent of Model Area Original Oil-in-Place

(3) Primary $=689.5+28.2 \mathrm{MBO}$ from Infills 
DATE: $09 / 21 / 01$ TIME: 09:31:56 FILE: LEA GETH: $\quad 0$

RESERVES AND ECONOMICS

READ \& STEVENS

7/27/01 NYMEX FUTURE STRIP
AS OF SEPTEMBER 1,2001
T. SCOTT HICKMAN \& ASSOC., INC PETROLEUM ENGINEERS CRV/00.004

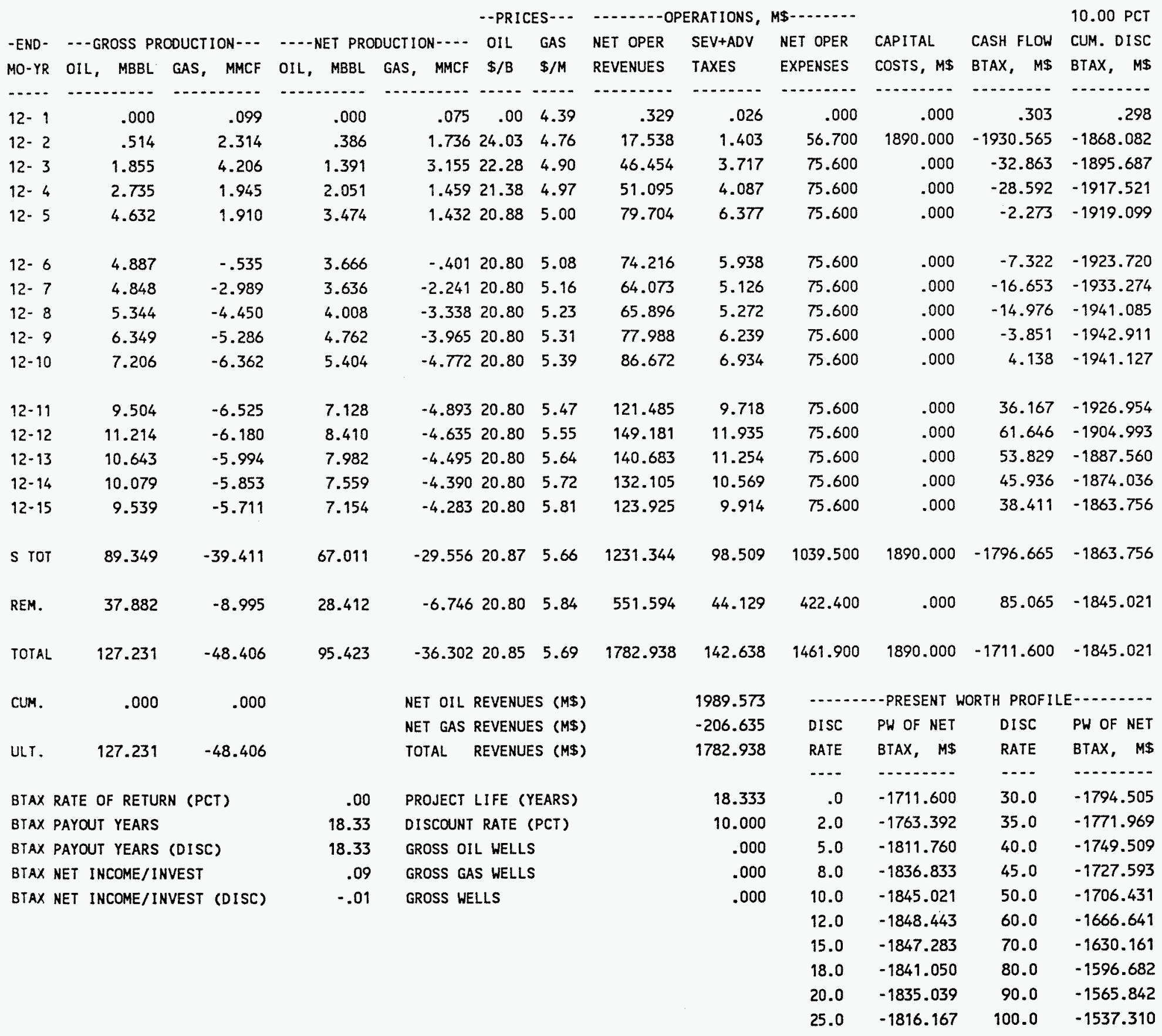


DATE: $09 / 21 / 01$ TIME: 09:31:56 FILE: LEA GETH: $\quad 0$

RESERVES AND ECONOMICS

READ \& STEVENS

$7 / 27 / 01$ NYMEX FUTURE STRIP
AS OF SEPTEMBER 1, 2001
T. SCOTT HICKMAN \& ASSOC., INC PETROLEUM ENGINEERS CRV/00.004

\begin{tabular}{|c|c|c|c|c|c|c|c|c|c|c|c|c|c|}
\hline \multirow{3}{*}{$\begin{array}{l}\text {-END- } \\
\text { MO-YR }\end{array}$} & & & & & & \multicolumn{2}{|c|}{--PRICES--. } & \multicolumn{2}{|c|}{ OPERATIONS, } & \multirow{2}{*}{ NET OPER } & \multirow{3}{*}{$\begin{array}{l}\text { CAPITAL } \\
\text { COSTS, MS }\end{array}$} & \multirow[b]{2}{*}{ CASH FLOW } & \multirow{2}{*}{$\begin{array}{l}10.00 \text { PCT } \\
\text { CUM. DISC }\end{array}$} \\
\hline & \multicolumn{3}{|c|}{--GROSS PRODUCTION--- } & \multicolumn{2}{|c|}{$-\cdots$ NET PRODUCTION--.. } & OIL & GAS & NET OPER & $S E V+A D V$ & & & & \\
\hline & Oll & L. MBBL & GAS, MMCF & OIL, MBBL & GAS, MMCF & $\$ / B$ & $\$ / M$ & REVENUES & TAXES & EXPENSES & & BTAX, M\$ & BTAX, M\$ \\
\hline$\cdots$ & & 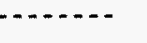 & $-\cdots+-\infty-n$ & $\cdots$ & n-n & $\ldots .$. & $\cdots$ & $\cdots+\cdots$ & $\cdots+\cdots$ & $\cdots+\cdots$ & $-\cdots$ & $\cdots+\cdots$ & 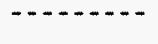 \\
\hline $12-1$ & & .000 & -1.263 & .000 & -.948 & .00 & 4.39 & -4.160 & -.333 & .000 & .000 & -3.827 & -3.766 \\
\hline $12-2$ & & .000 & -3.609 & .000 & -2.706 & .00 & 4.76 & -12.879 & -1.031 & 56.700 & 1890.000 & -1958.548 & -1898.002 \\
\hline $12-3$ & & .000 & -3.374 & .000 & -2.530 & .00 & 4.90 & -12.398 & -.992 & 75.600 & .000 & -87.006 & -1971.087 \\
\hline $12-4$ & & .003 & -4.218 & .003 & -3.163 & 21.67 & 4.96 & -15.638 & -1.251 & 75.600 & .000 & -89.987 & -2039.804 \\
\hline $12-5$ & & .404 & -9.589 & .303 & -7.191 & 20.88 & 5.01 & -29.665 & -2.373 & 75.600 & .000 & -102.892 & -2111.233 \\
\hline $12-6$ & & .853 & -14.475 & .639 & -10.856 & 20.80 & 5.08 & -41.859 & -3.349 & 75.600 & .000 & -114.110 & -2183.248 \\
\hline $12-7$ & & 1.435 & -18.159 & 1.076 & -13.619 & 20.80 & 5.16 & -47.843 & -3.827 & 75.600 & .000 & -119.616 & -2251.876 \\
\hline $12-8$ & & 3.483 & -19.356 & 2.612 & -14.517 & 20.80 & 5.23 & -21.649 & -1.732 & 75.600 & .000 & -95.517 & -2301.695 \\
\hline $12-9$ & & 5.496 & -20.691 & 4.122 & -15.518 & 20.80 & 5.31 & 3.302 & .264 & 75.600 & .000 & -72.562 & -2336.101 \\
\hline $12-10$ & & 7.323 & -21.415 & 5.492 & -16.061 & 20.80 & 5.39 & 27.634 & 2.211 & 75.600 & .000 & -50.177 & -2357.730 \\
\hline $12-11$ & & 9.005 & -22.473 & 6.754 & -16.855 & 20.80 & 5.47 & 48.241 & 3.859 & 75.600 & .000 & -31.218 & -2369.964 \\
\hline $12-12$ & & 11.515 & -23.194 & 8.636 & -17.395 & 20.80 & 5.55 & 83.002 & 6.640 & 75.600 & .000 & .762 & -2369.693 \\
\hline $12-13$ & & 16.048 & -20.181 & 12.036 & -15.136 & 20.80 & 5.64 & 165.009 & 13.201 & 75.600 & .000 & 76.208 & -2345.012 \\
\hline $12-14$ & & 15.564 & -18.763 & 11.673 & -14.073 & 20.80 & 5.72 & 162.263 & 12.981 & 75.600 & .000 & 73.682 & -2323.319 \\
\hline $12-15$ & & 14.973 & -17.488 & 11.229 & -13.116 & 20.80 & 5.81 & 157.378 & 12.591 & 75.600 & .000 & 69.187 & -2304.801 \\
\hline S TOT & & 86.102 & -218.248 & 64.575 & -163.684 & 20.80 & 5.39 & 460.738 & 36.859 & 1039.500 & 1890.000 & -2505.621 & -2304.801 \\
\hline REM. & & 147.198 & -111.820 & 110.400 & -83.866 & 20.80 & 6.20 & 1776.095 & 142.086 & 1147.200 & .000 & 486.809 & -2221.672 \\
\hline TOTAL & & 233.300 & -330.068 & 174.975 & -247.550 & 20.80 & 5.67 & 2236.833 & 178.945 & 2186.700 & 1890.000 & -2018.812 & -2221.672 \\
\hline CUM. & & .000 & .000 & & NET OIL & REVENUES & $S(M \$)$ & & 3639.510 & $\cdots$ & - -PRESENT $W$ & ORTH PROFIL & 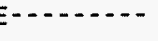 \\
\hline & & & & & NET GAS & REVENUES & $S(M \$)$ & & -1402.677 & DISC & PW OF NET & DISC & PH OF NET \\
\hline ULT. & & 233.300 & -330.068 & & TOTAL & REVENUES & $S(M \$)$ & & 2236.833 & RATE & BTAX， M\$ & RATE & BTAX, MS \\
\hline BTAX & RATE & OF RETURI & $V(P C T)$ & .00 & PROJECT & LIFE (YE & EARS) & & 26.333 & .0 & -2018.812 & 30.0 & -2003.665 \\
\hline BTAX & PAYOA & UT YEARS & & 26.33 & DISCOUNT & I RATE (PC & P(T) & & 10.000 & 2.0 & -2131.309 & 35.0 & -1953.889 \\
\hline BTAX & PAYO & UT YEARS & (DISC) & 26.33 & GROSS OII & IL WELLS & & & .000 & 5.0 & -2209.667 & 40.0 & -1909.240 \\
\hline BTAX & NET & INCOME/IN & VEST & -.07 & GROSS GA & AS WELLS & & & .000 & 8.0 & -2227.716 & 45.0 & -1869.151 \\
\hline BTAX & MET & INCOME/IN & VEST (DISC) & -.21 & GROSS WE & LLS & & & .000 & 10.0 & -2221.672 & 50.0 & -1832.994 \\
\hline & & & & & & & & & & 12.0 & -2207.366 & 60.0 & -1770.204 \\
\hline & & & & & & & & & & 15.0 & -2177.237 & 70.0 & -1717.210 \\
\hline & & & & & & & & & & 18.0 & -2142.303 & 80.0 & -1671.473 \\
\hline & & & & & & & & & & 20.0 & -2118.159 & 90.0 & -1631.273 \\
\hline & & & & & & & & & & 25.0 & -2058.774 & 100.0 & -1595.416 \\
\hline
\end{tabular}


RESERVES AND ECONOMICS

READ \& STEVENS

$7 / 27 / 01$ NYMEX FUTURE STRIP
AS OF SEPTEMBER $\quad 1,2001$
T. SCOTT HICKMAN \& ASSOC., INC PETROLEUM ENGINEERS CRV/00.004

\begin{tabular}{|c|c|c|c|c|c|c|c|c|c|c|c|c|c|}
\hline \multirow{3}{*}{$\begin{array}{l}\text {-END- } \\
\text { MO-YR }\end{array}$} & & & & & & \multicolumn{2}{|c|}{--PRICES--- } & \multicolumn{2}{|c|}{ OPERATIONS, } & \multirow{2}{*}{ NET OPER } & \multirow{3}{*}{$\begin{array}{l}\text { CAPITAL } \\
\text { COSTS, M\$ }\end{array}$} & \multirow[b]{2}{*}{ CASH FLOW } & \multirow{2}{*}{$\begin{array}{l}10.00 \text { PCT } \\
\text { CUM. DISC }\end{array}$} \\
\hline & \multicolumn{3}{|c|}{-.-GROSS PRODUCTION-.- } & \multicolumn{2}{|c|}{$\cdots$ NET PRODUCTION-..- } & OIL & GAS & NET OPER & $S E V+A D V$ & & & & \\
\hline & OIL & MBBL & GAS, MMCF & OIL, MBBL & GAS, MMCF & $\$ / B$ & $\$ / M$ & REVENUES & TAXES & EXPENSES & & BTAX, M\$ & BTAX, MS \\
\hline$\cdots$ & $\cdots$ & $\ldots$ & 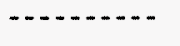 & (n... & $-\ldots$ & $\cdots-$ & $\cdots$ & $\cdots+\ldots$ & $\ldots \ldots$ & $\cdots-$ & $\cdots$ & .. & - \\
\hline $12-1$ & & .000 & .064 & .000 & .048 & .00 & 4.38 & .210 & .016 & .000 & .000 & .194 & .191 \\
\hline $12-2$ & & .514 & 1.843 & .386 & 1.382 & 24.03 & 4.76 & 15.853 & 1.268 & 94.500 & 2835.000 & -2914.915 & -2819.998 \\
\hline $12-3$ & & 1.855 & -.999 & 1.391 & -.749 & 22.28 & 4.90 & 27.321 & 2.186 & 126.000 & .000 & -100.865 & -2904.724 \\
\hline $12-4$ & & 4.748 & -6.996 & 3.561 & -5.247 & 21.38 & 4.96 & 50.084 & 4.006 & 126.000 & .000 & -79.922 & -2965.755 \\
\hline $12-5$ & & 7.753 & -9.939 & 5.815 & -7.455 & 20.88 & 5.01 & 84.104 & 6.729 & 126.000 & .000 & -48.625 & -2999.512 \\
\hline $12-6$ & & 10.723 & -10.107 & 8.043 & -7.580 & 20.80 & 5.08 & 128.787 & 10.303 & 108.000 & .000 & 10.484 & -2992.896 \\
\hline $12-7$ & & 13.213 & -11.297 & 9.910 & -8.472 & 20.80 & 5.16 & 162.443 & 12.996 & 108.000 & .000 & 41.447 & -2969.116 \\
\hline $12-8$ & & 13.393 & -13.922 & 10.045 & -10.442 & 20.80 & 5.23 & 154.286 & 12.343 & 108.000 & .000 & 33.943 & -2951.412 \\
\hline $12-9$ & & 13.428 & -13.675 & 10.071 & -10.256 & 20.80 & 5.31 & 154.996 & 12.400 & 108.000 & .000 & 34.596 & -2935.008 \\
\hline $12-10$ & & 13.120 & -12.537 & 9.840 & -9.403 & 20.80 & 5.39 & 153.972 & 12.318 & 108.000 & .000 & 33.654 & -2920.501 \\
\hline $12-11$ & & 12.530 & -11.661 & 9.397 & -8.745 & 20.80 & 5.47 & 147.598 & 11.807 & 108.000 & .000 & 27.791 & -2909.611 \\
\hline $12-12$ & & 11.920 & -10.924 & 8.940 & -8.193 & 20.80 & 5.55 & 140.441 & 11.236 & 108.000 & .000 & 21.205 & -2902.057 \\
\hline $12-13$ & & 11.308 & -10.300 & 8.481 & -7.725 & 20.80 & 5.64 & 132.850 & 10.628 & 108.000 & .000 & 14.222 & -2897.451 \\
\hline $12-14$ & & 10.704 & -9.757 & 8.028 & -7.318 & 20.80 & 5.72 & 125.104 & 10.009 & 108.000 & .000 & 7.095 & -2895.362 \\
\hline $12-15$ & & 10.127 & -9.245 & 7.595 & -6.933 & 20.80 & 5.81 & 117.705 & 9.417 & 108.000 & .000 & .288 & -2895.285 \\
\hline S TOT & & 135.336 & -129.452 & 101.503 & -97.088 & 20.86 & 5.37 & 1595.754 & 127.662 & 1552.500 & 2835.000 & -2919.408 & -2895.285 \\
\hline REM. & & 13.723 & -30.026 & 10.293 & -22.520 & 20.80 & 6.00 & 79.038 & 6.323 & 96.000 & .000 & -23.285 & -2900.469 \\
\hline TOTAL & & 149.059 & -159.478 & 111.796 & -119.608 & 20.85 & 5.49 & 1674.792 & 133.985 & 1648.500 & 2835.000 & -2942.693 & -2900.469 \\
\hline CUM. & & .000 & .000 & & NET OIL R & REVENUE & $E S(M \$)$ & & 2331.195 & $\cdots$ & - PRESENT $W$ & ORTH PROFIL & ED........ \\
\hline & & & & & NET GAS R & REVENUE & $=S(M \$)$ & & -656.403 & DISC & PW OF NET & DISC & PW OF NET \\
\hline ULT. & & 149.059 & -159.478 & & TOTAL & REVENUE & $E S(M \$)$ & & 1674.792 & RATE & BTAX, M\$ & RATE & BTAX, MS \\
\hline BTAX & RATE & OF RETURN & (PCT) & .00 & PROJECT L & LIFE CY & (EARS) & & 17.333 & .0 & -2942.693 & 30.0 & -2751.041 \\
\hline BTAX & PAYOU & UT YEARS & & 17.33 & DISCOUNT & RATE ( & (PCT) & & 10.000 & 2.0 & -2938.764 & 35.0 & -2713.128 \\
\hline BTAX & PAYOU & UT YEARS 6 & $(D I S C)$ & 17.33 & GROSS OIL & IL WELLS & & & .000 & 5.0 & -2927.889 & 40.0 & -2676.392 \\
\hline BTAX & NET I & INCOME/INV & VEST & -.04 & GROSS GAS & IS WELLS & & & .000 & 8.0 & -2912.525 & 45.0 & -2641.034 \\
\hline BTAX & NET I & INCOME/INV & JEST (DISC) & $=.06$ & GROSS WEL & LLS & & & .000 & 10.0 & -2900.469 & 50.0 & -2607.115 \\
\hline & & & & & & & & & & 12.0 & -2887.334 & 60.0 & -2543.581 \\
\hline & & & & & & & & & & 15.0 & -2866.166 & 70.0 & -2485.433 \\
\hline & & & & & & & & & & 18.0 & -2843.828 & 80.0 & -2432.128 \\
\hline & & & & & & & & & & 20.0 & -2828.542 & 90.0 & -2383.096 \\
\hline & & & & & & & & & & 25.0 & -2789.749 & 100.0 & -2337.818 \\
\hline
\end{tabular}


DATE: $09 / 21 / 01$ TIME: 09:31:56 FILE: LEA GETH: $\quad 0$

RESERVES AND ECONOMICS

READ \& STEVENS

7/27/01 NYMEX FUTURE STRIP
AS OF SEPTEMBER 1, 2001
RE $S$ ER $V$ E $S$ C $A$ N D
T. SCOTT HICKMAN \& ASSOC., INC PETROLEUM ENGINEERS CRV/00.004

-END- ---GROSS PRODUCTION---

MO-YR OIL, MBBL GAS, MMCF

$12-$

$12-$

12- 3

12- 4

12 . -

- -PRICES--$\cdots-N E T$ PRODUCTION-.-
OIL, MBBL GAS, MMCF $\$ / B$ GAS -...-OPERATIONS, M\$ NET OPER SEV+ADV NET OPER REVENUES TAXES EXPENSES

$\begin{array}{rrrr}.000 & 1.190 & .00 & 4.39 \\ -5.153 & -11.178 & 24.03 & 4.76 \\ -5.131 & -13.491 & 22.28 & 4.90 \\ -3.666 & -11.053 & 21.38 & 4.96 \\ -2.601 & -9.252 & 20.88 & 5.01\end{array}$

5.221

$-180.434$

$-100.616$

$\begin{array}{lll}-8.076 & 20.80 \quad 5.08\end{array}$ $\begin{array}{lll}-7.845 & 20.80 \quad 5.16\end{array}$ $-7.67620 .80 \quad 5.23$ $\begin{array}{lll}-7.400 & 20.80 & 5.31\end{array}$ $\begin{array}{lll}-7.793 & 20.80 \quad 5.39\end{array}$

$-8.33420 .80 \quad 5.47$

1.876

2.174

1.979

1.625

1.314

$-8.065$

23.714

15.649

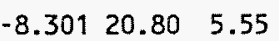

$\begin{array}{lll}-7.987 & 20.80 \quad 5.64\end{array}$

$\begin{array}{lll}-7.817 & 20.80 \quad 5.72\end{array}$

$\begin{array}{lll}-7.631 & 20.80 \quad 5.81\end{array}$

$-122.64424 .09 \quad 5.25$

$\begin{array}{lll}-8.258 & 20.80 \quad 5.35\end{array}$

$-130.90219 .10 \quad 5.26$

NET OIL REVENUES (M\$)

NET GAS REVENUES (M\$)

TOTAL REVENUES (M\$)

1.06 PROJECT LIFE (YEARS)

18.60 DISCOUNT RATE (PCT)

23.33

1.55

$-1.50$
GROSS OIL WELLS

GROSS GAS WELLS

GROSS WELLS
$-177.029$

$-133.255$

\section{$-78.883$}

$-61.252$

$-42.400$

$-19.404$

$-11.069$

$-6.589$

TAXES

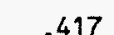

$-14.162$

$-14.434$

$-10.661$

$-8.049$

$-6.310$

$-4.900$

$-3.392$

$-1.552$

$-.885$

$-.891$

$-3.868$

$-10.935$

$-16.994$

$-838.398$

$-.527$

$-.071$

$-.310$

$-.874$

$-1.359$

$-67.069$

449.103

35.927

$-389.295$

$-31.142$

298.927

$-688.222$

$-389.295$

23.333
10.000
.000
.000
.000
$-55.200$

$-55.200$

223.200 -.

$$
2.0
$$$$
8.0
$$

10.00 PCT

CAPITAL CASH FLOW CUM. DISC

COSTS, M\$ BTAX, M\$ BTAX, M\$ DOD

$-37.800$

$-50.400$

$-50.400$

$-50.400$

$-50.400$

$-55.200$

$-55.200$

$-55.200$

$-55.200$

$-55.200$

$-55.200$

$-55.200$

100.000

-

4.804

4.728

100.000

$-225.067$

$-115.600$

$-207.706$

.000

$-72.194$

$-304.810$

.000

$-42.167$

.000

$\begin{array}{ll}-22.173 & -403.207\end{array}$

.000

.000

.000

$-1.152$

$-403.868$

$16.192-395.422$

$37.348 \quad-377.713$

.000

45.016

$-358.309$

\section{.000}

.000

.000

.000

.000

$49.138 \quad-339.054$

$54.380-319.682$

$51.642-302.958$

$45.139-289.669$

$39.565-279.080$

$-736.200$

100.000

$-135.12$

$-279.080$

.000

189.976

$-242.406$

$-513.000$

100.000

54.847

$-242.406$

PRESENT WORTH PROFILE-......-. DISC PW OF NET DISC PW OF NET RATE BTAX, M\$ RATE BTAX, M\$

$\begin{array}{lrr}\text { PROJECT LIFE (YEARS) } & 23.333 & \\ \text { DISCOUNT RATE (PCT) } & 10.000 & 2.0 \\ \text { GROSS OIL WELLS } & .000 & 5.0\end{array}$

10.0

BTAX,

54.847

....

30.0

$-289.865$

$-48.808$

35.0

$-282.563$

$-152.107$

40.0

$-274.139$

$-214.992$

45.0

$-265.419$

12.

$-242.406$

50.0

$-256.814$

15.

$-261.770$

60.0

$-240.703$

18.0

$-280.199$

70.0

$-226.423$

20.

$-289.995$

80.0

$-213.925$

25.0

-293.294
-294.465

$-203.002$

$-193.419$ 
DATE : 09/21/01 TIME: 09:31:56 FILE : LEA GET\#: $\quad 0$

RESERVES AND ECONOMICS

READ \& STEVENS

$7 / 27 / 01$ NYMEX FUTURE STRIP
AS OF SEPTEMBER 1,2001
T. SCOTT HICKMAN \& ASSOC., INC PETROLEUM ENGINEERS CRV/00.004

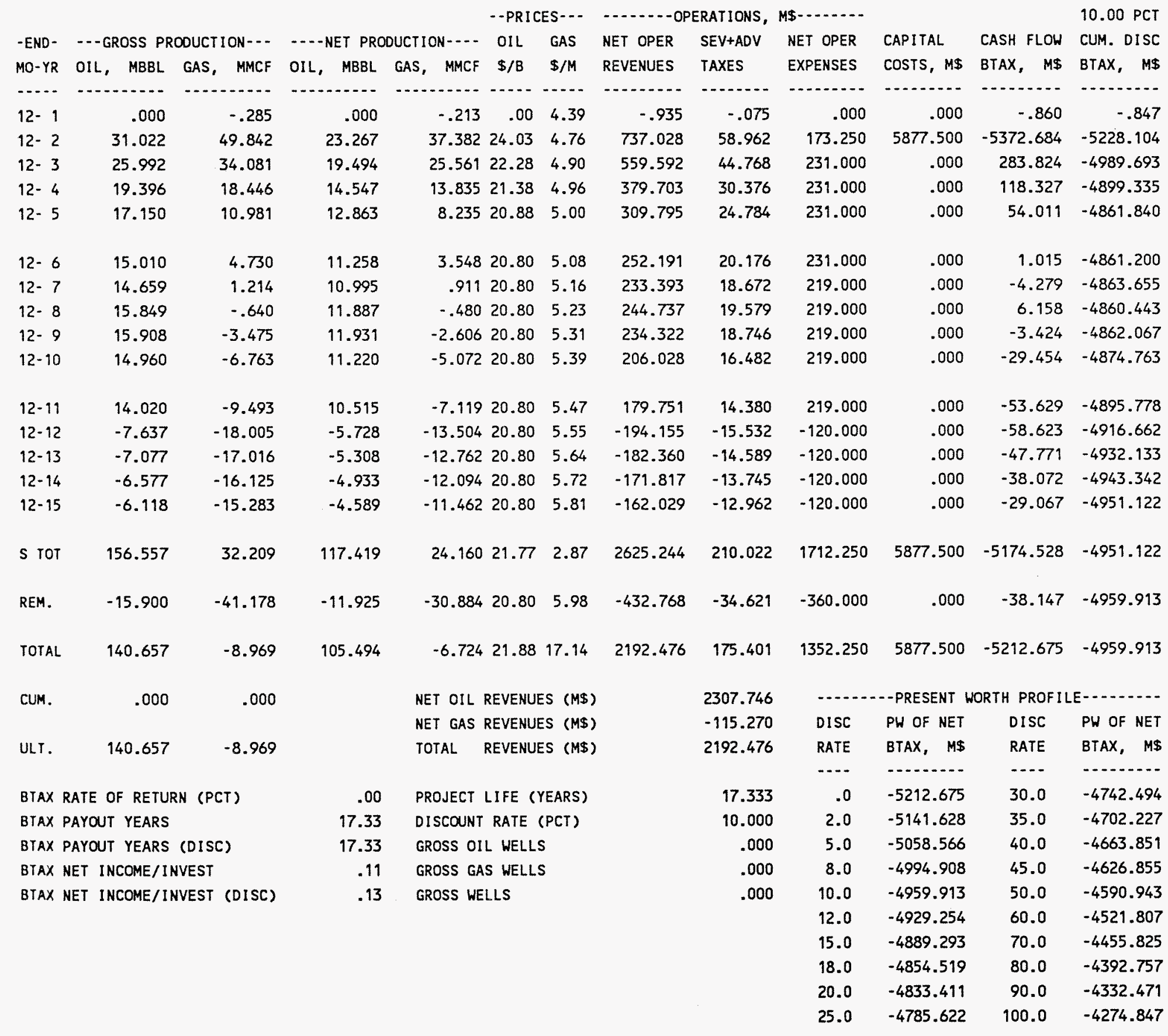


READ \& STEVENS

$7 / 27 / 01$ NYMEX FUTURE STRIP
AS OF SEPTEMBER 1,2001
T. SCOTT HICKMAN \& ASSOC., INC PETROLEUM ENGINEERS CRV/00.004

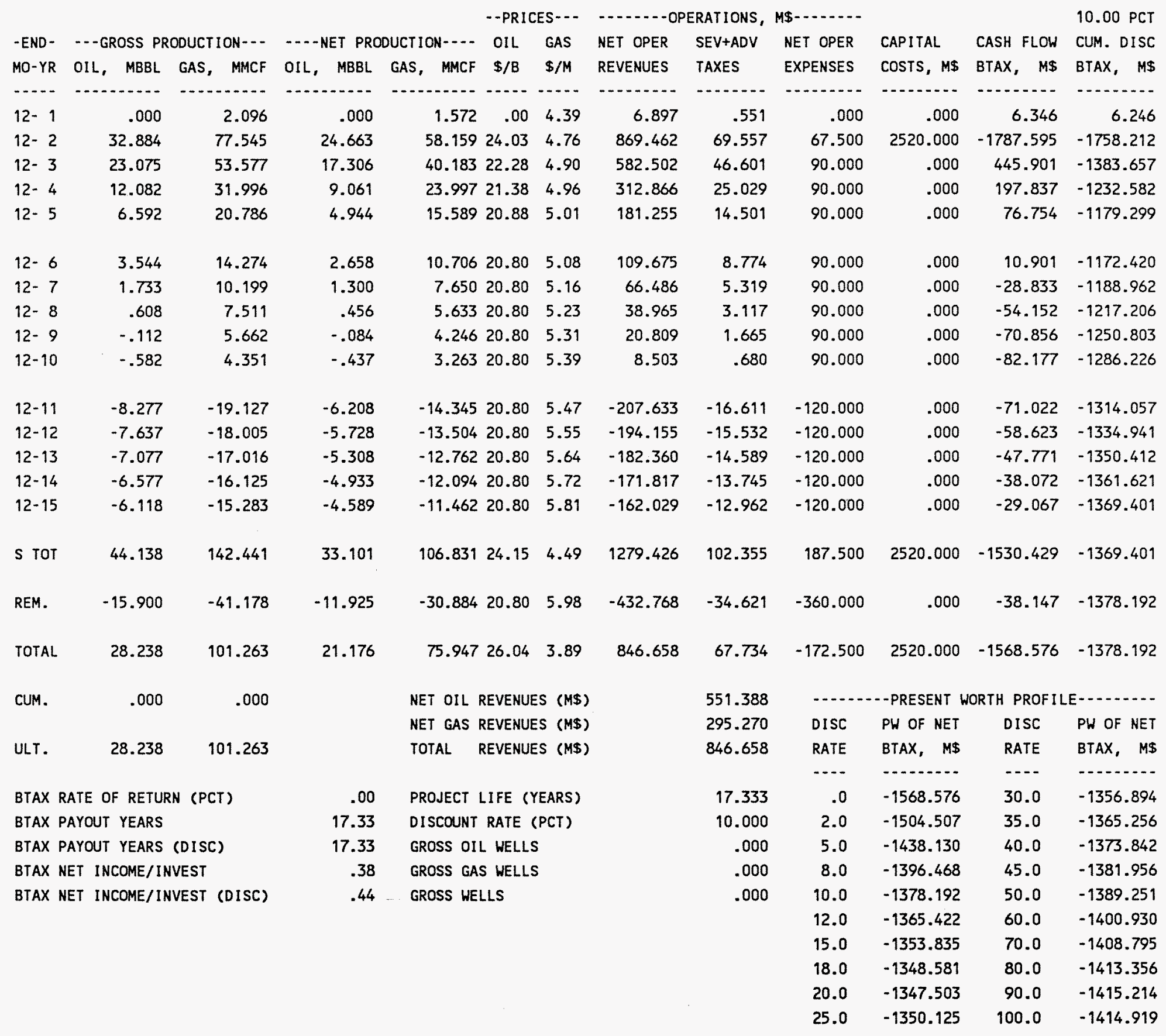


TABLE 8.

ECONOMIC DATA USED FOR

CASH FLOWS

\section{NORTHEAST LEA (DELAWARE) FIELD \\ LEA COUNTY, NEW MEXICO}

Completed well cost (producer)

$\$ 630,000$

Completed well cost (injector)

$\$ 472,500$

Conversion cost

$\$ 50,000$

Per-well monthly operating cost (producer)

$\$ 2,500$

Per-well monthly operating cost (injector)

$\$ 1,250$

Makeup water cost

20ф/barrel 